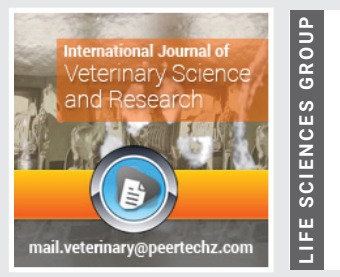

\section{Review on the implication on the control of transboundary and trade barrier animal diseases in Ethiopia}

\author{
Henok Mulatu Metaferiya ${ }^{1 *}$, Waziir Shafi ${ }^{2}$ and Henok Abebe ${ }^{3}$ \\ ${ }^{1}$ Habro District Livestock and Fish Resource Development Office, Gelemso, Ethiopia \\ ${ }^{2}$ Anchar District Livestock and Fish Resource Development Office, Cheleleka, Ethiopia \\ ${ }^{3}$ Hirna Regional Veterinary Laboratory, Hirna, Ethiopia
}

Received: 22 November, 2021

Accepted: 23 December, 2021

Published: 24 December, 2021

*Corresponding author: HHenok Mulatu Metaferiya, Habro District Livestock and Fish Resource Development Office, Gelemso, Ethiopia, Tel: +251912363554,

E-mail: henokmulatu5@gmail.com,

Mulatu.Metaferiya@haramaya.edu.et

ORCID: https://orcid.org/0000-0001-7358-4260

Keywords: Ethiopia; Transboundary animal diseases; International trade

Copyright License: (c) 2021 Metaferiya HM, et al. This is an open-access article distributed under the terms of the Creative Commons Attribution License, which permits unrestricted use, distribution, and reproduction in any medium, provided the original author and source are credited.

https://www.peertechzpublications.com

Check for updates

\title{
Summary
}

Transboundary Animal Diseases (TADs) are highly contagious diseases of livestock within the world. they need importance within the international trade of animals and animal products. With rapidly increasing globalization, associated risk of transboundary disease is emerging. They reduce production and productivity, disrupt local and national economies, and also threaten human health (zoonosis). Transboundary diseases are a priority globally, cumulative effort is required at the international level to attenuate the spread of infectious diseases across the borders. except for sub-Saharan African countries more particularly, eradication of most Transboundary animal diseases is impossible thanks to various technical, financial and logistical reasons like increased outbreaks of transboundary animal diseases droughts and market issues. In Ethiopia Transboundary animal diseases are endemic livestock diseases that cause market limits. This imposes far-reaching challenges for agricultural scientists on the critically important have to improve technologies in animal production and health so as to confirm food security, poverty alleviation and to assist the economic process. The international approach to the management of TADs is predicated on the belief that the majority is often eradicated. However, in developing countries, eradication of most TADs is difficult for a range of technical, financial and logistical reasons. General TADs combating strategies include prevention, early warning, early detection and early control.

\section{Abbreviations}

AHS: African Horse Sickness; BSE: Bovine Spongiform Encephalomalites; CBPD: Contagious BOVINE PLUEROPNEMONIA DISEASE; CCPPD: Contagious Caprine Plueropnemonia Disease; CSA: Central Statics Agency; DFID: Department for International Development; DFZs: Diseases Free Zones; EARO: Ethiopian Agriculture and Rural Development Office; FAO: Food and Agricultural Organization; FMD: Foot and Mouth Disease; KSA: Kingdom of Saudi Arabia; LCD: Less Developed Countries; LMM: Livestock Meat Market; LSD: Lumpy Skin Disease; MOA: Ministry of Agriculture; ND: Newcastle Disease; OIE: Office International des Epizootics; PPR: Pests des Petitis Ruminants; RVF: Rift Valey Fever; SPS: Sanitary Phyto-Sanitory; TADs: Transboundary Animal Aiseases; UAE: United Arab Emirates

\section{Introduction}

Livestock contributes 40 percent of the worldwide value of agricultural output, 5 percent of total food energy and 25 percent of dietary protein, and supports the livelihoods and food security of just about a billion people (FAO 2009). Ethiopia is thought for its livestock population which accounts first in Africa and tenth within the world and have the best work animal population within the continent. the location and variety of major agro-ecological zones of the country render a suitable environment for the support of enormous numbers and sophistication of livestock [1]. On the idea of statistics acquired from different sources, livestock provides $16 \%$ of the full GDP (equivalent to $30 \%$ of agricultural GDP) and generates $14 \%$ of the country's interchange earnings [2]. 
Even though the livestock sub-sector contributes much to the economic system, its development is hampered by different constraints. the foremost important constraints to cattle productions are widespread endemic diseases including viral, bacterial, and parasitic infestation, poor veterinary service and lack of attention from the government [3]. Moreover, the diseases make problems on international livestock markets and about 1.5-2.5 billion birr is annually lost from animal diseases [3].

However, market access from Africa has often been stymied by a range of constraints, including the prevalence of highly contagious transboundary diseases. These diseases are mostly eradicated within the developed world, but the fear of their entry from endemic reservoirs within the developing world precludes large-scale livestock product exports into lucrative markets within the international organization, US and Japan. Moreover, international trade regulations for meat products require zonal freedom from disease and don't heretofore distinguish between products (e.g., bone-in meat vs. deboned meat) in terms of their relative risk of spreading disease. Commodity-based approaches to trade, which instead specialize in the method by which products are produced (rather than their regional origin) in assessing their risk of disease, offer the potential for developing countries to export meat products that are lower in risk. Such new standards are being increasingly discussed in international circles [4-6].

Traditionally, trade, traffic and travel are instruments of disease spread. Now, changing climate across the world is adding to the misery. global climate change is creating a new ecological platform for the entry and establishment of pests and diseases from one nation-state to a different [7]. Several new transboundary diseases emerge, and old diseases reemerge, exhibiting increased chances for unexpected spread to new regions, often over great distances. Livestock enterprises and animal production contribute significantly to the global economy, provide a household source of income, food security, source of energy, draft power for crop cultivation, top quality animal proteins and vitamins (meat, milk), manure, raw materials (hides and skins) and gift [8], and generate a livelihood for 1.o billion poor people within the world [9]

From a substantial number of states, transboundary disease spread to other countries and reach epidemic proportions where control and management require cooperation between several countries [10]. They cause the most serious impact on animal and human livelihood as these have the potential to threaten food security, proper livelihood of livestock owners \& workers and rural economy which in certain instances may lead to political and social unrest in people. thanks to the world distribution and persistence of TADs world animal agriculture, food security and international trade are being very badly affected [11].

Transboundary animal diseases have a multi casual origin; some factors related to this process include Trade and international travel (increased frequency and speed of local and international travel, fostered by the globalization process promotes the spread of microorganisms on a world scale), changes in agricultural practices (animal domestication was one in every of the most promoters of microbial evolution by facilitating the supply of recent susceptible hosts at high densities, because of the intensification of livestock systems), temperature change (which causes changes in the ecogeographical distribution of vectors), reduction of habitat and increased contact with wild animals and introduction of immature wild and stock to new geographic areas where the disease is endemic and immunologically unknown for them $[12,13]$

However, various alternative options are initiated by different actors (private sector, governments and international organizations). These initiatives are often regional encompassing over one country in East Africa and try to find sound solutions to beat barriers to trade in order that Ethiopia and other countries could effectively use their rich livestock resources for the development of the live hood of their populations [14].

In Ethiopia, limited works has been done on TADs to this point and few works are reported on risk factors assessments, epidemiological aspects, seroprevalence and financial impacts in selected areas of the country. Therefore the objectives of this paper are:-

- To highlight major transboundary animal diseases and their economic impacts on international exchange Ethiopia

- To overview the varied management strategies and main constraints within the control and prevention of TADS.

\section{Transboundary animal diseases}

Transboundary livestock diseases are those that are of great economic, trade and food security importance for a substantial number of countries; which might easily spread to other countries and reach epidemic proportions; and where control/ management, including exclusion, requires co-operation between several countries. Transboundary diseases are highly contagious and have the potential for rapid spread, no matter national borders, causing serious socioeconomic consequences. All transboundary animal diseases have the potential to kill affected animals, but the severity of the disease will vary looking on factors like species and breed of animal, age, nutrition, disease agent, etc. Many TADs have 50 to 90 percent mortality rates in susceptible animals [10]

A characteristic of TADs is that they will be the reason behind national emergencies and their significance often transcends national boundaries. they're of particular importance to food security and sustained economic development and trade for several countries. Transboundary animal diseases are economic importance of nontariff barriers to the export of animals and their products. they're highly contagious and feared diseases of livestock within the world and of economic importance and a significant constraint in international trade [10].

Several infectious zoonotic diseases have recently emerged, causing devastating economic losses within the countries affected. These have a large-ranging impact on the livelihoods 
of farmers, and regional and international trade, food safety, public health and international travel and tourism. Disease pathogens still evolve and adapt themselves to animals and humans alike. Their investigation indicates that a lot of those new diseases emerge in response to a number of critical factors, like changes in climate, ecosystems, animal production systems and land use, all of which alter the interactions between pathogens and various hosts thus the number of developed countries is declared free from these diseases and that they prevent the introduction of the diseases to their countries by banning imports from infected developing countries thanks to the unrestricted importation of animals from infected countries and poor veterinary services [15].

\section{Global and national transboundary animal diseases}

The World Trade Organization (WTO) is an international reference body within the field of animal diseases and zoonoses recognize the globe Animal Health Organization (OIE). The OIE lists diseases that are considered to be of such significance thanks to their impact on animal populations, ability to spread and threat to human health that the Veterinary Authorities of member countries are required to notify OIE about changes to things regarding these diseases within the country [16]. OIE list of notifiable diseases are transmissible diseases that have the potential for very serious and rapid spread, regardless of national borders, that are of significant socio-economic or public health consequence which are of major importance within the international trade of animals and animal products. a number of the foremost important transboundary diseases are Foot and Mouth Diseases (FMD), African Swine Fever (ASF), Contagious Bovine Pleuropneumonia (CBPP), Rift valley fever (RVF), Avian Influenza (AI), Newcastle Disease (ND), Classical swine fever (CSF) and Peste des Petits Ruminants (PPR) [10,17].

\section{Global distribution of transboundary animal disease}

Transboundary animal diseases are easily transmitted from one country to a different, thanks to the rapid globalization including the rise of international exchange of domestic and wild animals and animal products, the expansion of human population, global climate changes, changes in agricultural production systems, and to microbiological adaptation. The common ways of introducing animal diseases to a replacement geographical location are through the entry of live diseased animals and contaminated animal products. Other introductions result from the importation of contaminated biological products like vaccines or protoplasm or via entry of infected people (in case of zoonotic diseases). Even migration of animals and birds, or natural spreading by insect vectors or wind currents, could also spread diseases across geographical borders [7]. International interchange of live animals and animal products offers opportunities for pathogens and vectors to be transported across oceans and continents. However, except for some documented examples, such as the multiplicity of routes of introduction, including active and passive dispersal of vectors, infected human, animal movements and migration, transportation of products and biological invasions like introduction, initial dispersal, establishment and spread, the particular contribution of globalization to disease emergence is inherently difficult to quantify (Lanciot, et al. 2004).

\section{Transboundary animal diseases in sub-Saharan Africa}

Livestock plays a key role within the agricultural economy of the many countries in Sub- Saharan Africa, contributing over $1 / 4$ of the full value of agricultural production. additionally to providing food, income, employment and interchange earnings, livestock is a source of wealth and supplier of inputs and services like draught power, manure and transportation. Despite these important roles, the expansion in livestock productivity in Sub-Saharan Africa has been below that of another developing region $[10,18]$. The present international approach to The management of TADs relies on the belief that almost all are often eradicated; consequently, that's the same old objective adopted by international organizations concerned with animal health [19]. However, for Sub-Saharan Africa and southern Africa more particularly, eradication of most TADs is impossible because of various technical, financial and logistical reasons like increased outbreaks of TADs droughts and market issues [20].

\section{Transboundary animal diseases in Ethiopia}

Distribution: Ethiopia has the most important herd in Africa. Livestock is central to the Ethiopian economy, contributing for $20 \%$ of the GDP, supporting the livelihoods of $70 \%$ of the population and generating about $11 \%$ of annual export earnings [21]. In Ethiopia, there are numerous records of the presence of major TADs. Rinderpest has been eradicated and lots of other endemic diseases are put under considerable control, there are still some serious TADs like CBPP, CCPP, FMD, LSD, AHS, PPR and ND which are limiting the productivity and international trade of livestock and their products [7]. Diseases like PPR, marek's disease, gumboro and maedi-visna were exotic to the country until some 15 years ago but are now common findings in indigenous livestock populations [17]. Foot and mouth disease FMD is one of the main diseases in Ethiopia that hampering export of livestock and livestock products to the center East and African countries; the Egyptian trade ban of 2005/2006, during which Ethiopia lost over US\$14 million [22].

Ethiopia set a target to extend exports of meat products to 30,000 tons by 2008 and eventually to 80,000 tons, most of which is able to have to be derived from cattle. However, Ethiopia has many endemic livestock diseases, including FMD that limit market access. Nonetheless, there's increased discussion in policy circles about developing appropriate certification systems to facilitate meat exports, particularly beef. While proposed certification systems would both fit the minimal disease risk principles advocated in CommodityBased Trade (CBT) circles and credibly deliver disease-free products that meet current trading standards, they could also limit competitiveness in international markets by virtue of high feeding costs related to improving quality. Indeed, with or without certification systems, Ethiopia remains within the "murky middle" from the standpoint of competitiveness in third markets. At present, Ethiopia is neither cost-competitive with low value suppliers to African markets such as India and Brazil nor is it competitive (with an SPS-certified, higher quality product) in higher value markets in the Middle East [6] 
Trade and economic impacts: The Horn of Africa is commonly considered as an area of the biggest informal transborder traded livestock movements within the world. the most cross-border markets are Wuchale, Dewele, Gashamo, Goladi and Ferfer within the east and Dolo Odo and Moyale within the south.In the west are Okobo, Bambudeo, Kumruk, Humera and Almahal. Livestock trading networks penetrate deep into Ethiopia's Somali Region where many of the animals are raised. Throughout this geographical area, animals are both trekked and trucked to their final destinations. Through the crossborder markets, Ethiopia is linked with markets within the Arabian Peninsula and also the Gulf through Djibou , Somaliland and Puntland via the Ports of Djibou, Berbera, Bosasso [23] and with Tertiary markets in Kenya (Nairobi, Mombasa) and Sudan (Khartoum). The main secondary markets are located within the main towns and cities across the country, while Addis Ababa, the capital city could be a tertiary market [23-26]. It's very difficult to convincingly establish the approximate size of informal cross-border livestock trade transactions thanks to the unregulated nature of the operation. However, there's clear evidence that the biggest proportion of livestock trade operations within the eastern Africa region is characteristically directed through the unofficial channel [26-28].

The informal trans-border pastoral trading system during this region have resiliently survived and flourished under the region's distressing conditions of political rivalry, armed conflicts, unpredictable border closures, and storms of other restrictive interventions [26]. The flourishing prevalence of informal cross-border livestock trade flows within the peripheral territories of nations within the region is arguably an easy re-establishment of the longstanding indigenous pattern of intensive barter exchange and transboundary population migrations which pre-date colonial and post-colonial borders [29].

The key motivational factors are both economic and social, principally including entailed high transaction costs within the formal channel, poor access to formal export markets which are often controlled by the central elite (and often characterized by unfair transaction deals), and also the strong prevalence of fraternalism and socio-cultural ties among pastoral communities that transcend artificial national borders. The overwhelmingly large infrastructural and personnel requirements of authorized flows and custom services along these extensive national borders also clearly necessitate clean ICBT activities to be conducted without adherence to the procedural requirements of formal institutions within the prevailing dismal conditions of poor infrastructure and inadequate institutional provisions of the center $[26,27]$. Transboundary animal diseases impose major social and economic costs and risks to infected countries, their neighbors, and trading partners. The varying impact of TADs among stakeholders and therefore the threat to existing and potential exchange wealthier countries complicates the question of appropriate control. For all livestock producers, the threat of TADs increases the chance of lost production and impacts livelihood, increasing vulnerability to poverty particularly for small-scale producers. Foot and Mouth Disease is one of the key endemic transboundary livestock diseases of socioeconomic importance in Ethiopia and other parts of the world. The impact of FMD in Asia in 1996 in terms of loss of feed sales alone has been estimated at over USD 500 million; persistent contagious bovine. pleuropneumonia and African swine fever still cause high economic damage to ruminant producers in Sub-Saharan Africa. The impact of TADs and their control vary reckoning on the pathogenicity of disease, a number of animals in danger, dependency on livestock for a livelihood, and method of control [10].

The socio-economic significance of PPR may be a result of heavy losses at the production level and market effects along the worth chain. it's estimated that $10 \%$ of the full impact of the disease is on trade and public expenditure and $90 \%$ on herd productivity [30]. In Ethiopia, FAO estimated that losses related to PPR reached a mean of US\$ 375 per flock annually with a median of 143 small ruminants per flock (an average loss of over US\$2 per animal) [31]. They reduce productivity on a clinical and sub-clinical level. They cause production losses like reduced weight gains, impairing growth, lowered milk and meat production, high veterinary costs and mortalities, especially among the young [32].

\section{Control of transboundary and trade barrier animal di- seases}

Due to multiple adverse impacts, it's necessary to effectively manage the TADs. If an introduction of TADs will be recognized early whilst it's localized and so a disease control program be quickly implemented, the prospects for eradication of the disease with minimal production losses and other costs are markedly enhanced. Conversely, if the disease is allowed to become well established within the country, eradication could also be very costly and difficult. Accordingly, there are two key TADs combating principles early warning and early reaction [16].

a. Early warning: This refers to rapid detection of the introduction of, or outburst within the incidence of TADs. It embraces all initiatives, mainly supported disease surveillance, reporting and epidemiological analysis that will cause improved awareness and knowledge of the distribution and behavior of disease outbreaks and which permit forecasting of the source and evolution of the disease outbreaks and also the monitoring of the effectiveness of disease control campaigns [16].

b. Early reaction: This suggests holding out immediately the disease control activities needed to contain the outbreak and so to eliminate the disease and infection within the shortest possible time-frame and within the most cost-effective way [16]. The key strategies are:

c. Strong border Control: This encompasses preventing the incidence of TADs and disease-transmitting vectors; minimizing the movement of animals across the borders and prompt practice of quarantine protocol. Geographic system (GIS) and remote sensing can be utilized as early warning systems and within the surveillance and control of infectious diseases [33]. 
d. Early warning/Early reaction: Ensuring appropriate preparedness and response capacity to any emerging disease. Keeping in sight that emerging infectious diseases are a continuing threat, it's necessary to own early disease detection capacity so implement a timely response [34].

e. Breaking disease transmission cycles: The humanlivestock-wildlife transmission of infections should be interrupted and surveillance of TADs must focus at the wildlife- livestock interface must [35].

f. Regional/International cooperation: This involves establishing a regional biosecurity arrangement with the capacity for an early disease warning system for surveillance, monitoring and diagnosis of TADs [36]. Since TADs are a priority globally, a cumulative effort is required at the international level to reduce crossborder transmissions [34]. Strong Policy Support: government policies should work effortlessly to boost animal research and capacity building, and technological development [36].

g. Breeding management: Undertaking animal breeding strategies to form disease-resistant gene pools. Enhancing host genetic resistance to disease by selective breeding of resistant animals could be a smart strategy to enhance the immunity of animals to counter invading infections [37].

h. Environmental protection: Heating and global climate change predispose animals to newer infections. Therefore, man-made disasters that have adverse implications on climate should be reduced or avoided [7].

International coordination is crucial for the control and elimination of TADs. Rinderpest was eradicated thanks to the concerted efforts by national authorities; the support of reference laboratories for confirmatory diagnosis or vaccine development and internal control and investment by the international community within the establishment of regional approaches and networks of laboratories and epidemiological units [1]. Surveillance and monitoring of animal diseases and international disease control programs are divided among three organizations: the OIE, the Food and Agriculture Organization of the United Nations (FAO), and also the World Health Organization (WHO). The OIE Animal Health system provides official information for early warning purposes and details of the worldwide situation for over 100 animal diseases and zoonoses. The FAO provides technical assistance in handling TADs. The WHO has an "alert and response team" for human diseases, including zoonoses. additionally, there are unofficial networks like ProMED-mail, which is an electronic outbreak reporting system that monitors emerging infectious diseases globally [38]

Global Early Warning and Response System (GLEWS) for major animal diseases including zoonoses, a joint FAO, OIE and WHO initiative which mixes the strengths of the three organizations to realize common objectives. Through sharing of knowledge on disease outbreaks and epidemiological analysis the GLEWS initiative aims at improving global early warning likewise as transparency among countries. The response component of the GLEWS are complementing the prevailing response systems of FAO, OIE and WHO (in the sector of zoonosis) so as to deliver rapid coordinated international response to disease emergencies. Jointly, the three organizations are going to be able to cover a wider range of outbreaks or exceptional epidemiological events with the supply of a wider range of experience $[39,40]$.

Control of transboundary and trade barrier diseases in Ethiopia: Animal health is that the biggest constraint on the trade of livestock and its products in Ethiopia. There are about 7-8 OIE list of notifiable diseases of trade and economic significance and other animal diseases of zoonotic importance within the country. Food safety is of accelerating importance worldwide, especially in developed countries [41]. Certification for freedom from additional health hazards, like BSE and drug and chemical residues in livestock products, are now frequently included in trade protocols to further guarantee food safety [42]. Animal welfare issues also are important. Various alternative options are either proposed or initiated by different actors (private sector, governments and international organizations) [43]. These initiatives are often regional encompassing over one country in geographical area and try and find sound solutions to beat barriers to trade so that Ethiopia and other countries could effectively use their rich livestock resources for the development of the livelihood of their populations [44].

Establishment of Disease-Free Zones (DFZs): The OIE Terrestrial Animal code specifies the rules for safe animal and animal material trade. These guidelines specify that LLP must originate from countries or specified geographical areas of a rustic (zone) that are free from major animal diseases, capable of causing economic losses or human diseases. Like other developing countries, constrained by these international regulations Ethiopia is considering the establishment of DFZs in Borena, Ogaden and Afar areas [43]. Ethiopia has 6 quarantine stations: Jijiga, Mile, Adama, Dire Dawa, New Flower and Metema. Adama and Dire Dawa export their animals via Port of Djibouti, the most destinations being Yemen, KSA, UAE, Egypt, while Jijiga quarantine station is served by Port of Babera in Somaliland, Somalia. Metema within the west caters for animals destined for the Republic of Sudan, with the aim of expediting movement through Dibouti as a transit country. The services offered include vaccination against FMD and brucellosis, and quarantine period as specified by the importing countries [26].

General Requirements of a DFZ per the OIE, a zone developed as free for a selected disease, must meet the subsequent requirements: The zone must be demarcated from the remainder of the country by appropriate natural, artificial or legal barriers; livestock inhabiting within the zone must be permanently identified; Adequate disease surveillance must be observed within the zone to enable detection of specific diseases; Specimens collected from suspected diseased animals must be tested at approved diagnostic laboratories 
using methods that are per the OIE manual; The zone must be holding unvaccinated livestock that are liable to the particular disease, except within the case of FMD (vaccination possible) [45]. There must be adequate livestock movement controls into the zone to forestall introduction of disease (may necessitate the establishment of breeding stocks within the designated DFZ); The integrity of the zone must be ensured through appropriate legislation; Transparency in reporting any changes to the disease situation or integrity of the zone (to be verified through a reputable audit system) is important [17].

\section{DFZ in pastoral settings}

Establishment of DFZs to be located in Afar, Ogaden and Borena areas of Ethiopia [43]. the subsequent strengths and weaknesses are identified basically on feasibility, competitiveness and sustainability grounds. Strengths: With the establishment of DFZs, there'll be an increased animal value within the zone, which can be beneficial for both farmers and traders [44].

Weaknesses: the subsequent main factors will pose considerable and negative influence on the competitiveness and sustainability of DFZs in pastoral areas of Ethiopia: (i) fulfilling all WTO/SPS regulations and OIE requirements for DFZ are very difficult; (ii) huge investment over an extended period of time is required no matter the stated impediments. Details of weaknesses of building DFZs in pastoral setting in Ethiopia could also be conventionally classified into two major categories: Veterinary and Husbandry Practices; and Socioeconomic, Cultural and Geographic Factors, as illustrated below [44].

\section{Veterinary and husbandry practices}

Diseases: High prevalence of trade-sensitive diseases (OIE List A diseases) within the pastoral ecosystems will still pose serious challenges for the very success of the envisaged DFZs, Presence of untamed animals often sharing the identical grazing grounds with domestic stocks, will and function reservoirs of infection to the latter, Poor (critically inadequate) veterinary services in most pastoral localities will cause obvious and heavy difficulties in eradicating these disease and sustenance of DFZs [43]

Feed and water. Crucial shortage of feed and water for livestock in these areas for many parts of the year. This, as well as recurrent drought scenarios, will cause a nonstop challenge to take care of an adequate number of export and breeding stocks within defined DFZs, warranting a desire to develop suitable strategies and expensive investments that guarantee the regular and adequate provision of livestock feed and water [45]. Herd registration. Implementation of herd registration (recording), could be also a prerequisite for the establishment of DFZs, Adequate numbers of breeding commercial ranches within the designated DFZs are needed to confirm the continuous supply of livestock for export and the assembly of breeding replacements. These are currently lacking and difficult to implement within the pastoral setting thanks to social, cultural and economic reasons. Robust national policies and associated regulations for herd registration; animal movement and certification similarly because the capacity to strengthen it are required [45].

\section{Socio-economic, Cultural and Geographic Fac- torsControl of animal movements}

The pastoral areas are generally featured by the presence of established tans-humans tradition (movement of both people and livestock). On the opposite hand, control of animal movements is one of the elemental bases and prerequisites for DFZ establishment. Restrictions of movements of individuals and animals within DFZs will make it difficult for both the pastoralists inside and out of doors the zone. Control of prevailing TADs through rigorous control of animal movements is thus difficult to realize because it is appeared to stand against the present cultural set-up and social practices of pastoral communities. On the opposite hand, an increased animal value within the DFZs will create net inward movement of livestock from the buffer and other areas. Establishing and maintaining DFZ boundaries will undoubtedly be a significant challenge in these environments [45].

Cross-border trades, often illicit, are long-standing features. additionally, harmonizing of livestock trade has to date been difficult thanks to lack of interest, on the part of the neighboring countries. Promoters (individuals/group, organized or otherwise) of Illicit (informal) trades have vested interests. Enhanced livestock development projects like DFZs may evoke outcomes that contradict their interests. These individuals/groups, because it is mostly the case for other issues, may pose physical threats and render the sustainability of DFZs questionable [46].

Establishment of export zones - production and market export systems: An export zone is one where measures are in situ to satisfy all the wants of a selected importer or set of importers for a selected commodity or range of commodities that aren't fulfilled within the exporting country as a full. the target is to confirm the supply of commodities of predetermined quality while concomitantly reducing the danger of importation of human and animal pathogens to an agreed level. Export Zones differ from DFZs, as defined by the OIE's Terrestrial Animal code, in two respects. Disease-free zone as defined by the code, apply to individual diseases while the concept of 'Export Zone' covers all major animal diseases that have control on trade within a selected zone. The 'Production Export Systems' enable livestock to be bred and raised in an exceedingly biosecure, but not necessarily infection-free production system [47] Figure 1.

The technical implementation processes include: Isolation of animals within the zone from contact with those outside the zone, Prevention of entry of probably contaminated products (e.g. animal feeds), vehicles and fomites across the border of the export zone. Identification of animals within the export zone and maintenance of an adequate data base with information on the origins and life history of the animal population within the export zone. Regular application of animal health control measures like a vaccination against identified infections (e.g. RVF \& and FMD). Maintenance of export standards at the

Citation: Metaferiya HM, Shafi W, Abebe H (2021) Review on the implication on the control of transboundary and trade barrier animal diseases in Ethiopia. Int $\mathrm{J}$ Vet Sci Res 7(2): 201-210. DOI: https://dx.doi.org/10.17352/ijvsr.000101 


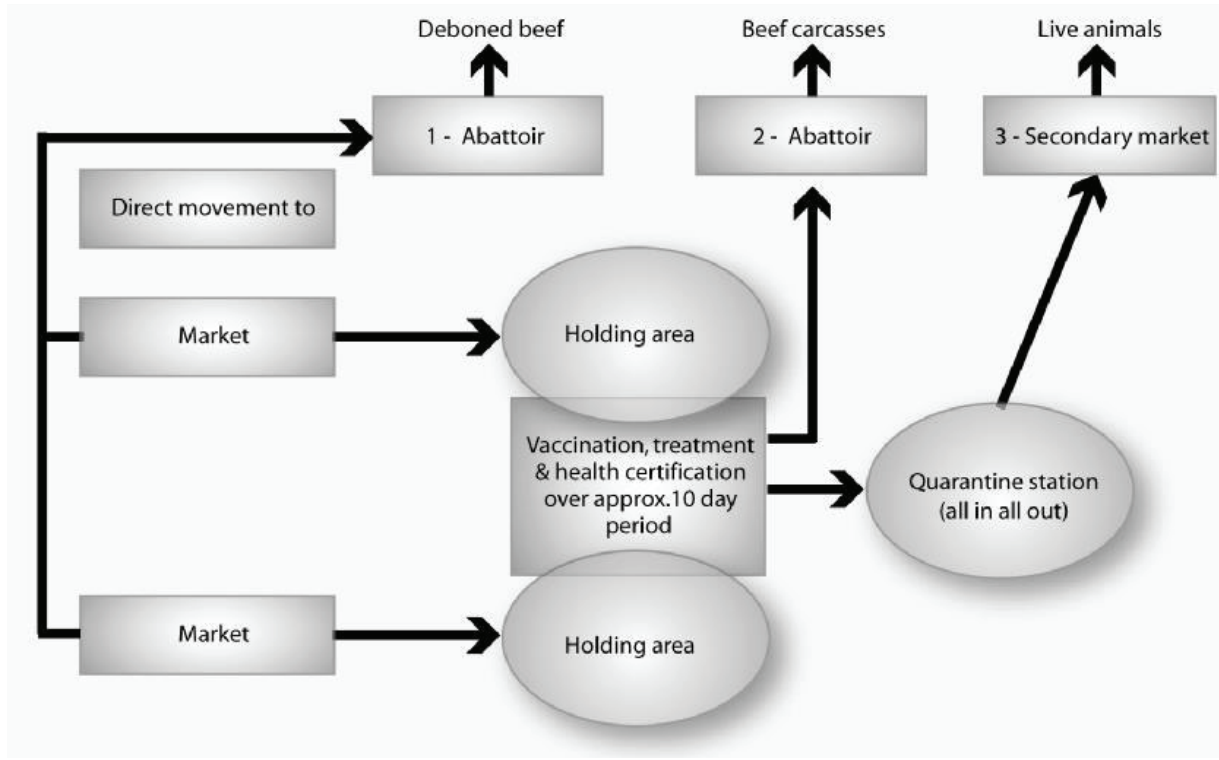

Figure 1: Diagrammatic Representation of Different Processes Required to Effectively Reduce the Risk of Spreading transboundary animal diseases Source: Thompson, et al. [19]

abattoir(s), measures to confirm isolation of the products from the export zone from contamination once they are moved through the remainder of the country to the purpose of export [45].

Strengths: These new concepts have a scientific basis to suit and be guided by international norms (WTO, SPS Agreement and OIE Recommendations). Export zone systems enable exports from a little rustic during which, generally, there are insufficient resources or infrastructure to fulfill all the export requirements for the establishment and sustenance of DFZs. It allows to concentrate the resources necessary to ascertain or initiate exports in a very relatively small area then render the method affordable in countries where financial resources are limited. Avoid having to institute stringent export-related requirements (e.g. livestock movement control) in parts of the country that don't seem to be involved in exports and which can not benefit directly from those exports [48]. Weaknesses: The technical requirements for such zones with regard to infrastructure, animal health requirements, legislation and regulation described for the establishment of DFZs also will hold true here. The export zone systems must not be considered as the cheapest option. These options are expensive and logistically difficult to implement. Huge investment, both by the general public and personal sectors is significant from the beginning. The difference in investment between DFZs and Export Zones could be a matter of magnitude/scale [43].

Examination and certification of livestock for export: The main goal of the Examination and Certification of livestock for export (EXCELEX) project is to support the livestock exports from the Horn of Africa. The project at the start of its implementation innovate the target zones in three countries in a geographic area, namely Ethiopia (Somali region), Djibouti and Somalia (Somaliland and Puntland) and includes a generation of two years [40].
The EXCELEX system to be recommended by the project will hinge on traditional livestock exporting practices. Initial health inspections are extended closer to the areas where the livestock originate. At that time they'll be individually identified and licensed. If necessary, vaccinations also will lean. After a period of no but 14 days, they'll receive a second inspection and their serum is tested for brucellosis. The animal individual identification, it'll be possible to work out if the animals are carrying any of the targeted diseases, where these animals originated, and who was involved within the inspection and movement of these animals. After the second inspection, livestock is going to be cleared to proceed to the embarkation phase of the export process, which mustn't be but 21 days from the date of the primary inspection[40]. Strengths: improving the livelihood of pastoral communities through resumption of livestock export is theoretically commendable and innovative; The EXCELEX understand the features and patterns of livestock movements within the project localities; the system may admit providing clues and help to point where within the trade route infections might need been acquired; It also lays grounds for sound animal movement control within the future; Apart from fostering information exchange, it'll function a mechanism of filling market intelligence gaps; The EXCELEX project could be a relatively small one, in terms of its budget, and with a relatively short span of life. It attempts to handle specific issues associated with livestock ban within the specified areas in three neighboring countries [16].

Weaknesses; the three different countries with considerable differences in their capacities to supply animal health services. Harmonization and sustenance of those various arrangements is difficult; undergoing various levels of internal conflicts (e.g. Somalia), this has resulted in a disruption of state services and destruction of infrastructure. this may render uncertain the implementation, success and sustainability of the project; Livestock trade the project areas is featured with illicit (informal) 
trade.The outflow of livestock from Ethiopia makes the country in an absolute disadvantaged position. The EXCELEX system doesn't allow the isolation of animals. additionally, cost and logistic difficulties, vaccination of livestock isn't encouraged by the system. due to this, the probability of occurrence of disease outbreak or exporting of infected subjects will relatively be high and the target areas where political instability and conflict may be a common $[16,40]$.

\section{Challenges in dealing with transboundary animal di- seases}

Transboundary animal diseases are a permanent threat for livestock keepers. They have major economic implications: both through the private and public costs of the outbreak, and thru the price of the measures taken at individual, collective and international levels so as to forestall or control infection and disease outbreaks $[7,34]$

Several challenges confront the strategies to combat TADs. The most important ones are requirement of novel systems having the capacity of real-time surveillance of emerging diseases. For this, research and repair-oriented scientific technology are necessary at regional levels. Research emphasis has got to get on specific detection and identification of the infectious agents, need for epidemiological methods to assess the dynamics of infections within the self and neighboring countries/regions. Need for research and development of disease diagnostic reagents that don't need refrigeration(cold chain) [48-50].

More importantly, they ought to be readily available likewise as affordable, to be used in pen-side test format; There are many diseases that there's an inadequate supply of vaccines or there are not any vaccines available. Insufficient or lack of vaccine hampers the disease control programs. have to build up vaccine banks for stockpiling the important vaccines to implement timely vaccination; Required availability of costeffective intervention or disease control strategies. whether or not a technology is offered, it's to be cheaper to adopt at the purpose of use; Need for ensuring public awareness of epidemic animal diseases. Many farmers are unaware of the emerging diseases. As such, unless reported to a concerned regional authority, an emerging disease may go unnoticed; Shortage of state and personal funding for research on emerging disease problems [7,51-74].

The government similarly as industries addressing animal health should take initiative and appropriate sponsorship during this regard and Inadequate regulatory standards for safe international trade of livestock and livestock products. Otherwise, there would be a compromised situation in disease control strategies $[34,41]$.

\section{Conclusion and recommendation}

Livestock constitutes a very important component of world agriculture. Increasing movement of human population, livestock and livestock products within and across countries, and climate changes, have worsened the impact of TADs.
TADs Transboundary animal diseases reduce production and productivity, disrupt local and national economies, and also threaten human health. This imposes far-reaching challenges for agricultural scientists on the critically important have to improve technologies in animal production and health so as to confirm food security, poverty alleviation and to help the economic process. Transboundary animal diseases will be introduced into a rustic or region by various means, mainly through legal and illegal importation of animals and animal products. Transboundary animal diseases are not any respecters of national boundaries. The control and eradication efforts of individual countries could also be continually frustrated by reintroduction of disease across their borders. The eradication of TADs therefore can only be achieved through international cooperation and punctiliously coordinated regional and global programs. The eradication of renderpest was a typical indicator of such coordination. Consequently, border control is taken into account a wonderful defense against the occurrence of the many TADs. there's a desire for increased ability to detect the clinical signs of highly contagious diseases and therefore the ability to differentiate them from similar afflictions. Thus disease knowledge and awareness on the part of animal health professionals and livestock producers are important steps in preventing the spread of TADs. Weakened (decentralized) chain of command has resulted in inadequate disease reporting, inadequate exchange of disease/animal health information among national, regional, zonal and districts level, and lack of harmonized disease-control programmes. Therefore, integrated TADs management measures are required to safeguard the livestock industry and to uphold safe international trade of livestock and their products.

Therefore, from the above conclusions the following points are recommended:

$>$ The government gives unique awareness on provisions associated with routine surveillance and early detection of TADs.

$>$ Awareness creation on the impact of transboundary animal diseases.

> Capacity building for veterinary professionals for detection and prognosis of by the use of OIE-indexed tests.

> Improvement in security, communication, and focus amongst stakeholders in control of illegal border trade.

$>$ Expansion of standardized quarantine area and forage production.

> Uniform and strong livestock office and legislation should be implemented in federal, regional, zonal and district level as structure of ministry of health.

\section{References}

1. FAO (2011) The Global Rinderpest Eradication Programme. Progress report on rinderpest eradication: Success stories and actions leading to the June 2011 Global Declaration. 
2. CSA (2016) Agricultural sample survey 2010/2011. Report on livestock and livestock characteristics. Central Statistical Agency of Ethiopia. Statistical Bulletin 505. Link: https://stanford.io/3ql9J67

3. Zewdie S (2004) Current status of veterinary services in Ethiopia. In proceedings of a national workshop on managing animal health constraint to export marketing of meat and livestock.

4. Thomson GR, Tambi EN, Hargreaves SK, Leyland TJ, Catley AP, et al. (2004) International trade in livestock and livestock products: the need for a commodity- based approach. Vet Rec 155: 429-433. Link: https://bit.ly/3muD9hh

5. Scoones +, Wollmer W, Mapitse N, Moerane R, Penrith ML, et al. (2008) Footand-mouth disease and market access: challengesfor the beef industry in southern Africa. Transboundary animal disease and market access: future options for the beef industry in southern Africa. Link: https://bit.ly/32fSonn

6. Rich KM, Perry BD, Kaitibie S (2009) Commodity-based trade and market access for Emerge. Infect Dis 10: 2067-2072.

7. FAO (2008) Expert meeting on climate related transboundarypests and diseases including relevant aquatic species. FAO headquarters, 25-27 February 2008. Rome, Italy. Link: https://bit.ly/3ekoLDw

8. Gari G, Bonnet P, Roger F, Waret-Szkuta A (2011) Epidemiological aspects and financial impact of Lumpy skin disease in Ethiopia. Prev Vet Med 102: 274-283. Link: https://bit.ly/32ln72h

9. Naqvi S, Sejian V (2011) Global climate change:Role of livestock. Asian J Agriculture Sci 3: 19-25. Link: https://bit.ly/3qkarR7

10. Otte MJ, Nugent R, McLeod A (2004) Transboundary animaldiseases: Assessment of socio-economic impacts and institutional responses. Livestock policy discussion paper No. 9. FAO, Rome, Italy. Link: https://bit.ly/3HcNdmH

11. Domenech J, Ubroth J, Eddi C, Roger F (2006) Regional and international approaches on prevention and control of animal transboundary and emerging diseases. Ann N Y AcadSci 1081: 90- 107. Link: https://bit.ly/30YRlrg

12. Chomel B, Belotto A, Meslin F (2007) Wildlife, Exotic Pets and Emerging Zoonoses. Emerg Infect Dis 13: 6-11. Link: https://bit.ly/3sAYPMn

13. Brown C (2010) Emerging Diseases: The Global Express. Vet Pathol 47: 9-14 Link: https://bit.ly/3pxS1NT

14. Ministry of Information (MOI) (2005) Export products of Ethiopia. Press release of Ministry of Information, Department of press and audiovisual. Addis Ababa, Ethiopia. Link: https://bit.ly/3ellRxy

15. FAO (2002) Improved animal health for poverty reduction and sustainable livelihoods. FAO Animal Production and Health Paper 153. Rome. Link: https://bit.ly/3yTpQMl

16. FAO (2004) Transboundary Animal Diseases. Assessment of socio-economic impacts and institutional responses. Livestock policy discussion paper 9 . Link: https://bit.ly/3EnDHeH

17. FAO and OIE (2004) Global Framework for the Progressive Control of Transboundary Animal Diseases (GF-TADs). Version approved as basic text Food and Agriculture Organization of the United Nations (FAO), Rome, Italy. Link: https://bit.ly/32wZeV2

18. Tambi EN, Maina OW, Mukhebi AW, Randolph TF (2000) Economic impact assessment of Rinderpest control in Africa. Rev Sci Tech Int Epiz 18: 458-477. Link: https://bit.ly/3JfCFFp

19. Thomson GR, Dungu B, Tounkara K, Vosloo W, Bastos A, et al. (2003) Suitability of currently available vaccines for controlling the major transboundary diseases that afflict sub-Saharan Africa. Dev Biol 114: 229-241. Link: https://bit.ly/32rdajL
20. Thomson GR (2009) Currently important animal disease management issues in sub- Saharan Africa. Onderstepoort J Vet Res 76: 129-134. Link: https://bit.ly/3Fs0ebO

21. SPS-LMM (2010) Focus on Ethiopia's Meat and Live Animal Export.Trade Bulletin 1.

22. Leforban $Y$ (2005) Report of a mission on foot and mouth disease in Ethiopia. Proposals for strategic plan for a control program oriented to the export 12-42.

23. Majid N (2010) Livestock Trade in the Djibouti, Somali and Ethiopian Borderlands. Chatham HouseBriefing Paper, September.manual. FAO Animal Health.

24. Umar A, Ruth T (2007) Risk Taking for a Living: Trade and Marketing in the Somali Region of Ethiopia. UN OCHA-PCI, Addis Ababa, Ethiopia. Link: https://bit.ly/32oZANZ

25. Mahmoud H (2010) Livestock Trade in Kenyan, Somali and Ethiopian Borderlands. Chatham House Briefing Paper, September. Link: https://bit.ly/30UusFe

26. Desta SW, Berhanu A, Sebsibe GE (2011) Informal Cross Border Livestock Trade in the Somali Region. FAO Regional Initiative in Support to Vulnerable Pastoralists and Agro-Pastoralists in the Horn of Africa, FAO Policy Brief developing country livestock products: the case of beef exports from Ethiopia. International Food and Agribusiness Management Review 12: 1-22.

27. Little P (2007) Unofficial Cross-Border Trade in Eastern Africa. A Pape presented at FAO workshop on Staple Food Trade and Market Policy Options for Promoting Development in Eastern and Southern Africa. Rome, March 1-2.

28. Little P (2009) Hidden Value on the Hoof: Cross-Border Livestock Trade in Eastern Africa. COMESA Policy Brief Number 2, February. Link: https://bit.ly/3qlEfwS

29. Ogalo V (2010) Informal Cross-Border Trade in EAC: Implications for Regional Integration and Development. CUTS International, Research Paper. Link: https://bit.ly/32opOzZ

30. DFID (2002) Annual Report, Department for International Development: 1-73. Link: https://bit.ly/3swW3rl

31. Wakhusama S, Sinkala Y, Chisemebele CC (2011) Rapid assessment on peste des petits ruminants (ppr) situation in Zambia, Vacnada, AU-IBAR 1-16.

32. Swai ES, Kapaga A, Kivaria F, Tinuga D, Joshua G, et al. (2009) Prevalence and distribution of Peste des petitsruminants virus antibodies in various districts of Tanzania. Vet Res Commun 33: 927-936. Link: https://bit.ly/3mrMpmk

33. Martin V, De Simone L, Lubroth J (2007) Geographic information systems applied to the international surveillance and control of transboundary animaldiseases, a focus on highly pathogenic avian influenza. Vet Ital 43: 437 450. Link: https://bit.ly/3pnn7r5

34. Hitchcock P, Chamberlain A, Van Wagoner M, Inglesby TV, O'Toole T (2007) Challenges to global surveillance and response to infectious disease outbreaks of international importance. Biosecur Bioterror 5: 206-227. Link: https://bit.ly/3en07jW

35. Siembieda JL, Kock RA, McCracken TA, Newman SH (2011) The role of wildlife in trans- boundary animal diseases. Anim Health Res Rev 12: 95-111. Link: https://bit.ly/3muJGsl

36. Rweyemamu MM, Musiime J, Thomson G, Pfeiffer D, Peeler E (2006) Future control strategies for infectious animal diseases- Case study of the UK and sub-Saharan Africa. In: UK Government's foresight project, infectious diseases: preparing for the future 1-24.

37. Gibson JP, Bishop SC (2005) Use of molecular markers to enhance resistance of livestock to disease: A global approach. Rev Sci Tech 24: 343-353. Link: https://bit.ly/3EodyN6

Citation: Metaferiya HM, Shafi W, Abebe H (2021) Review on the implication on the control of transboundary and trade barrier animal diseases in Ethiopia. Int $\mathrm{J}$ Vet Sci Res 7(2): 201-210. DOI: https://dx.doi.org/10.17352/ijvsr.000101 
38. CAST (2005) Global Risks of Infectious Animal Diseases. Council for Agricultural Science and Technology, USA. Link: https://bit.ly/3eoCnON

39. WHO (2004) Terrestrial Animal Health Code. ( $12^{\text {th }}$ edn), World Organization for Animal Health (OIE), Paris 554

40. FAO, OIE and WHO (2006) Global Early Warning and Response System for Major Animal Diseases, including Zoonoses (GLEWS). World Health Organisation, Geneva, Switzerland. Link: https://bit.ly/3FqQyyl

41. OIE Regional Representation for the Middle East, Beirut.

42. WTO (1998) Understanding the WTO Agreement on Sanitary and Phytosanitary Measures. Link: https://bit.ly/3Epa7ps

43. Ministry of Agriculture (MOA) (2002) Draft document on the establishment of Disease- free zones, Ministry of Agriculture, Ethiopia, 23.

44. MoARD (2004) Proceedings of a National Workshop on Managing Animal Health Constraints Export Marketing of Meat and Livestock - TCP/ETH/2907 - Rehabilitating and safeguarding livestock trade through establishing disease-free zones, 27 and 28 April 2004, Addis Ababa, Ethiopia 42.

45. FAO (2012) Strategy for Progressive Control of PPR in Ethiopia. Food and Agriculture Organization of the United Nations and Ethiopia. Addis Ababa, Ethiopia.

46. MoARD (2009) Ethiopia Freed from the most dangerous Cattle disease Ministry of Agriculture and Rural Development. Animal and Plant Health Regulatory Directorate. Addis Ababa, Ethiopia.

47. OIE (2013) Chapter 2.1: import risk analysis. In Terrestrial Animal Health Code.

48. FAO/OIE (2012) The global foot and mouth disease control strategy: Strengthening animal Health systems through improved control of major diseases. Link: https://bit.ly/3ejfWdi

49. Admassu B (2009) Establishing the baseline disease control experience with the control of transboundary animal diseases (TADS) in the Horn of Africa. In Proc. Joint African Union-Interafrican Bureau for Animal Resources/ United States Agency for International Development Workshop on Trade and Transboundary animalDiseases in the Horn of Africa, 30 March - 3 April, Nairobi. Link: https://bit.ly/3FsGrZE

50. Alemayehu T (2015) Assessment on the Challenges of Meat Export in Ethiopia (Doctoral dissertation, St. Mary's University). Link: https://bit.ly/3qfOGSA

51. Anand S, Hanson K (2006) Disability-adjusted Life Years: a Critical Review. J Health Neglected Zoonoses in the Industrialized World Emerge Inf dis 16: 17 Link: https://bit.ly/33L5w44

52. Basagoudanavar SH, Hosamani M (2013) TransboundaryDiseases of Animals: Mounting Concerns. Vetscan 7: 119. Link: https://bit.ly/3EtuuBE

53. Berhanu A (2002) Welcome address: animal health and poverty reduction strategies In:Proceedings of the $16^{\text {th }}$ Annual Conference of the Ethiopian Veterinar Association VA), held 5-6 June, 2002, Ghion Hotel, Addis Ababa Ethiopia 117-137.

54. Biruk A (2017) Review on Common Impact and Management of Transboundary Animal Disease. J Virol Curr Res 2: 555-583. Link: https://bit.ly/3FsKHZ5

55. Bonnet P, Lancelot R, Seeger's H, Martinez D (2011) World organization for animal health. Seventy ninth General sessions, World Assembly, Paris. 22-27.

56. Cutler S, Books A, Vander Poel W (2010) Public Health Threat of New, Reemerging and Neglected Zoonosis in Industrialized World. Emerg infect dis 16: 1-7. Link: https://bit.ly/3EjIGNG

57. Davis FG (2006) Risk of a Rift Valley fever epidemic at the Haj in Mecca, Saudi
Arabia. In Biological disasters of animal origin. The role and preparedness of veterinary and public health developing countries. J Anim Sci 85: 2788-2800.

58. Ethiopia Animal Health Yearbook 2009/10. Addis Ababa, Ethiopia. Link: https://bit.ly/3sxpwSk

\section{FAOSTAT (2007) Database. Link: https://bit.ly/30W2BVj}

60. FAO (1999) Recognizing Peste des Petits Ruminants field manual. Rome, Italy. Link: https://bit.ly/3mxkWiV

61. FAO (2011) A value chain approach to animal diseases risk management Technical foundations and practical framework for field application. Animal Production and Health Guidelines. No. 4. Rome. Link: https://bit.ly/3yUnBID

62. Fauci A, Touchette N, Folkers G (2005) Emerging Infectious Diseases: A 10-Year Perspective from the National Institute of Allergy and Infectious Diseases. Emerg Infect dis 11: 519-525. Link: https://bit.ly/3HcD1uO

63. Gulima D (2010) Disease reporting. Presentations on VACNADA Project close out workshop, $5^{\text {th }}$ to $7^{\text {th }}$ December 2011, Debre-Zeit, Ethiopia.

64. Hailemariam T, Legese G, Alemu D (2009) Market Structure and Function for Live Animal and Meat Exports in Some Selected Areas of Ethiopia. Research Report 79. Link: https://bit.ly/3yVciQg

65. Legesse Y, Asfaw Y, Sahle M, Ayelet G, Jenberie S, et al. (2012) First confirmation of foot and mouth disease virus serotype SAT-1 in cattle and small ruminants in Ethiopia in 2007/08. Trop Anim Health Prod 45: 1265-1267. Link: https://bit.ly/3poWS3L

66. McLeod A, Leslie J (2000) Livestock Policy Discussion Paper, No. 3, FAO/ AGAL.Socioeconomic Impacts of Freedom from Livestock Disease and Export Promotion in Developing Countries, of livestock in human nutrition and health for poverty reduction.

67. OIE (2007) Cost of National Prevention Systems for Animal Disease and Zoonoses in Developing and Transition Countries. Prepared by Civic Consulting. Link: https://bit.ly/3ssXTcY

68. Okello A, Paul E, Gibbs J, Vandersmissen A, Welburn S (2011) One Health and the Neglected Zoonoses: Turning Rhetoric into Reality. Vet Rec 169: 281-285. Link: https://bit.ly/3JdkNLp

69. Paarlberg PL, Seitzinger AH, Lee JG (2007) Economic impacts of regionalization of a highly pathogenic avian influenza outbreak in the United States. Journal of Agricultural and Applied Economics 39: 325-333. Link: https://bit.ly/3mxQOnL

70. Pepin M, Bouloy M, Bird B, Kemp A, Paweska J (2010) Rift Valley feveVirus (Bunyaviridae:Phlebovirus): an update on pathogenesis, molecule epidemiology, vectors, diagnostics and prevention. Vet Res 41: 61. Link: https://bit.ly/3ejF8k3

71. Rich KM, Perry BD (2011) The economic and poverty impacts of animal diseases in developing countries: New roles, new demands for economics and epidemiology. Prev Vet Med 101: 113-147. Link: https://bit.ly/32rdz5L

72. Rushton J (2013) An Overview Analysis of Costs and Benefits of Government Control Policy Options. Proc. Livestock Disease Policies: 'Building Bridges between Science and Economics'. International workshop held in OECD, Paris, France 3-4 June 2013

73. Seine ZC (1998) Perspectives of Veterinary Services in Latin America in the face of globalization. Second FAO Electronic Conference on Veterinary Services, FAO. Link: https://bit.ly/3Fs0CqM

74. Yehia G (2009) RVF related trade constraints in the Middle East. Presentation at a Meeting on RVF Modeling and Risk Analysis for the Middle East, 29 May, Paris.

Citation: Metaferiya HM, Shafi W, Abebe H (2021) Review on the implication on the control of transboundary and trade barrier animal diseases in Ethiopia. Int J Vet Sci Res 7(2): 201-210. DOI: https://dx.doi.org/10.17352/ijvsr.000101 